\title{
Incomplete suppression of parathyroid hormone activity in sarcoidosis presenting
} with hypercalcaemia

\author{
R. R. GHOSE* \\ F.R.C.P.
}

\author{
J. S. WOODHEAD $\dagger$ \\ B.Sc., Ph.D.
}

\author{
R. C. BROWN $\ddagger$ \\ B.Sc., Ph.D.
}

*Department of Medicine, Singleton Hospital, Sketty, Swansea, †Welsh National School of Medicine, Universiț Hospital of Wales, Heath Park, Cardiff and $\ddagger$ Welsh National School of Medicine, University Hospital of Wale Heath Park, Cardiff

\begin{abstract}
Summary
An adult patient presenting in summertime with sarcoidosis and demonstrating raised levels of serum calcium and 1,25-dihydroxycholecalciferol was observed to have a serum immuno-reactive parathyroid hormone concentration in the mid-normal range. Renal function was normal. Corticosteroid administration quickly depressed serum calcium and 1,25dihydroxycholecalciferol into the normal range; serum parathyroid hormone also fell to low levels.

It was concluded that corticosteroid suppression, when incorporating measurements of serum calcium and 1,25-dihydroxycholecalciferol concentrations, can distinguish between sarcoidosis-related hypercalcaemia and primary hyperparathyroidism. The significance of the changes in parathyroid hormone concentration is obscure.
\end{abstract}

KEY WORDS: sarcoidosis, hypercalcaemia, corticosteroid suppression.

\section{Introduction}

Hypercalcaemia accompanying sarcoidosis is due to a rise in circulating active vitamin D metabolite, 1,25-dihydroxycholecalciferol (1,25-DHCC). Moreover, corticosteroid administration produces a simultaneous decline in serum calcium and 1,25-DHCC concentrations (Bell et al., 1979; Zerwekh et al., 1980). In these studies, serum immunoreactive parathyroid hormone (PTH) concentration was suppressed to very low levels in the presence of hypercalcaemia. Serum PTH concentration is generally low in sarcoidosis, but may be elevated when there is co-existent primary hyperparathyroidism (Cushard et al., 1972). In hypercalcaemia arising from primary hyperparathyroidism, the serum PTH level may remain within the normal range, particu- larly when there is no evidence of skeletal involve ment (Addison et al., 1971). We report a case of hypercalcaemia associated with sarcoidosis in which the serum PTH level was higher than expected for the level of serum calcium concentration in the absenge of primary hyperparathyroidism.

\section{Case report}

A 39-year-old female presented in August $\overline{1} \$$ with a 2-month history of thirst, anorexia, constipstion, and loss of weight of $2 \mathrm{~kg}$. Physical examination revealed a rash on the right forearm, together with hepato-splenomegaly. Blood pressure was $120 / 8$ $\mathrm{mmHg}$.

Investigations: Erythrocyte sedimentation ra敦 (Westergren) $34 \mathrm{~mm}$ fall in $1 \mathrm{hr}$. Serum calcium concentration $3.46 \mathrm{mmol} /$ litre, albumin $39 \mathrm{~g} /$ lit $\overline{\mathrm{e}}$, creatinine $106 \mu \mathrm{mol} /$ litre. Serum biochemistry was otherwise normal. ${ }^{51}$ CrEDTA clearance, 90 $\mathrm{ml} / \mathrm{min} / 1.73 \mathrm{~m}^{2}$. Chest radiograph showed diffuse fibrotic changes in both lung fields. Lung functio tests revealed mild obstructive airways disease, bot no defect in transfer factor. Skeletal and abdomin $\mathrm{X}$-rays were normal. Skin biopsy of the rash on the forearm revealed non-caseating giant cell systems characteristic of sarcoidosis.

\section{Methods}

Serum calcium concentration was measured Technicon auto-analyser, using venous blood in the fasting state obtained from an unconstricted vein. Serum 25-hydroxycholecalciferol (25-HCC) w庐 measured by radio-immunoassay following protef precipitation with acetonitrite and extraction of the 


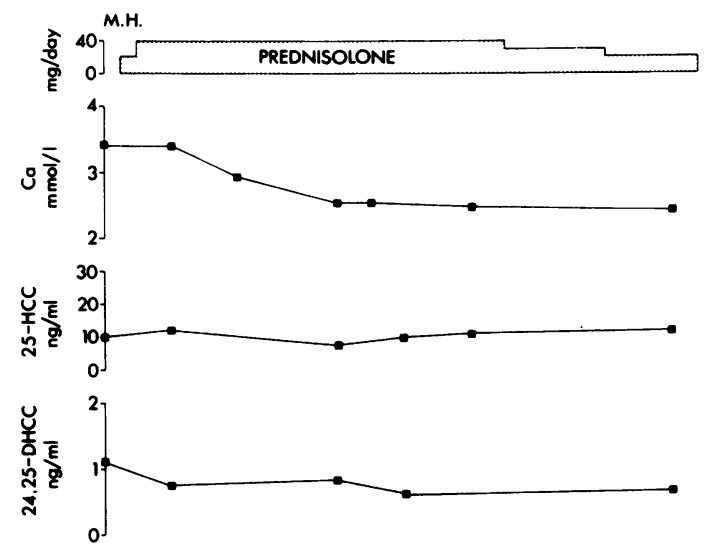

sured from a 2-hr urine collection, with venous blood obtained at the mid-point, on which calcium, inorganic phosphate and creatinine concentrations were determined. From these variables, TmP/GFR was derived by nomogram (Walton and Bijvoet, 1975) (normal range $0.7-1.4 \mathrm{mmol} /$ litre). ${ }^{47} \mathrm{Ca}$ absorption test was performed according to the technique of Chanard et al. (1974) (normal range-40-75\%).

\section{Results}

The presenting values and the effects of corticosteroid suppression on serum calcium, 25-HCC, 24, 25DHCC, 1,25-DHCC, and PTH concentrations, together with tubular maximum reabsorption rate with respect to glomerular filtration rate (TmP/GFR), are displayed in Fig. 1. Calcium absorption was measured before and after corticosteroid administration, when fractional calcium absorbed $6 \mathrm{hr}$ after ${ }^{47} \mathrm{Ca}$ was given was $72.5 \%$ and $52.5 \%$ respectively.

In January 1982, when the patient was off steroids, serum calcium was $2.35 \mathrm{mmol} /$ litre, $25-\mathrm{HCC}$ was 3.9 $\mathrm{ng} / \mathrm{ml}, 24,25-\mathrm{DHCC}$ was $0 \cdot 30 \mathrm{ng} / \mathrm{ml}, 1,25-\mathrm{DHCC}$ was $34.4 \mathrm{pg} / \mathrm{ml}$, and PTH was $0.66 \mathrm{ng} / \mathrm{ml}$.

\section{Discussion}

$1,25-\mathrm{DHCC}$ is generally believed to be synthesized exclusively in the renal cortex by $1 \alpha$ hydroxylation of 25-HCC (DeLuca and Schnoes, 1976). In sarcoidosis, however, an extra-renal source of 1,25-DHCC has been demonstrated in an anephric patient who developed hypercalcaemia (Barbour et al., 1981). The mechanism and control of this extra-renal synthesis is not understood, but it was speculated that 1,25DHCC synthesis occurred within active sarcoid tissue. Thus, exposure to sunlight may stimulate 1,25DHCC production at sites of active sarcoid granuloma formation. In a detailed case-report (Papapoulos et al., 1979) sequential biochemical and hormonal estimations in blood were performed over several years, and it was evident that hypercalcaemia developed in summer and was accompanied by a small rise in serum 25-HCC, which remained within the normal range, and a considerable rise in serum 1,25-DHCC, which far exceeded the normal range. Seasonal hypercalcaemia is well recognized in sarcoidosis (Taylor, Lynch and Wysor, 1963).

In our case, serum calcium and 1,25-DHCC concentrations were raised, while serum $25-\mathrm{HCC}$ was normal. However, a surprising finding was a serum PTH concentration of $0.5 \mathrm{pg} / \mathrm{ml}$. Such a value is inappropriate in the presence of hypercalcaemia. Patients who are hypercalcaemic as a consequence of malignant disease or vitamin $\mathrm{D}$ intoxication invari- 
ably have serum PTH levels below the detection limit of the assay $(0.2 \mathrm{ng} / \mathrm{ml})$, unless marked renal insufficiency is present. While a low TmP/GFR value in itself is of little significance, the observed finding on admission of $0.65 \mathrm{mmol} /$ litre is consistent with inappropriate PTH secretion, and the rise observed after commencing corticosteroid therapy corresponded to a fall in PTH secretion.

The prompt fall in serum calcium and 1,25-DHCC concentration following corticosteroid administration could have resulted from immune suppression of sarcoidosis and inhibition of extra-renal 1,25-DHCC production. The fall in serum 1,25-DHCC levels probably affected gut absorption of calcium. Serum PTH, in this case, rose transiently and then fell to undetectable levels; the mechanism of these changes is obscure. Most PTH antisera cross-react with molecular fragments, while the assay used recognizes in particular the biologically inert carboxy-terminal portion of the PTH molecule. Since PTH degradation occurs in liver and kidney, it is possible that abnormal metabolism of PTH may result from involvement of the liver with sarcoidosis, or to renaltubular damage secondary to hypercalcaemia, which may have contributed to the inappropriate serum PTH level. Glomerular function was not reduced to an extent that would have caused delayed clearance of the PTH fragments.

The association of sarcoidosis with primary hyperparathyroidism is well known (Dent and Watson, 1966; Winnacker et al., 1969), and a recent report revealed that 23 cases have been described (Robinson, Kerwin and Tsou, 1980). In a patient with biopsy-proven sarcoidosis and hypercalcaemia, in whom bone $\mathrm{X}$-rays fail to demonstrate periosteal reabsorption, the serum PTH level, and the response to corticosteroid administration (Anderson et al., 1954) are important diagnostic aids. Typically the hypercalcaemia of primary hyperparathyroidism is unaffected, whereas the serum calcium returns to normal in sarcoidosis. By extending the test to incorporate measurements of serum 1,25-DHCC and PTH, valuable diagnostic information may be obtained. Similarly high values of serum 1,25-DHCC have been observed in sarcoidosis (Papapoulos et al., 1979), and primary hyperparathyroidism (Broadus et al., 1980), ranging from $40-140 \mathrm{pg} / \mathrm{ml}$. In the present case, corticosteroids reduced serum 1,25-DHCC from 100 to $15 \mathrm{pg} / \mathrm{ml}$; the response in primary hyperparathyroidism is undefined.

\section{Acknowledgment}

We are grateful to Miss Julie E. Davies for secretarial assistange

\section{References}

Addison, G.M., Hales, C.N., Woodhead, J.S. \& O'RioRda J.L.H. (1971) Immunoradiometric assay of parathyroid hormog Journal of Endocrinology, 49, 521.

Anderson, J., Dent, C.E., Harper, C. \& Philpot, G.R. (195థ Effect of cortisone on calcium metabolism in sarcoidosis with hypercalcaemia: Possibly antagonistic actions of cortisone aurd vitamin D. Lancet, ii, 720.

Barbour, G.L., Coburn, J.W., Slatopolsky, E., Norman, A. \& HORST, R.L. (1981) Hypercalcaemia in an anephric patient with sarcoidosis: evidence for extra-renal generation of 1,25-dibydrof vitamin D. New England Journal of Medicine, 305, 440.

Bell, N.H., Stern, P.H., Pantzer, E., Sinha, T.K. \& Delu国, H.F. (1979) Evidence that increased circulating 1,25-dihydroxy tamin $D$ is the probable cause for abnormal calcium metabolisin in sarcoidosis. Journal of Clinical Investigation, 64, 218.

Broadus, A.E., Horst, R.L., LANG, R., LitTledike, E.T. \$ RASMUSSEN, H. (1980) The importance of circulating 1,297 dihydroxyvitamin $\mathrm{D}$ in the pathogenesis of hypercalciuria a renal-stone formation in primary hyperparathyroidism. NRO England Journal of Medicine, 302, 421.

Chanard, J., Assailly, J., Bader, C. \& Funck-Brentana, J.E. (1974) A rapid method for measurement of fractional intestina absorption of calcium. Journal of Nuclear Medicine, 15, 588.

Clemens, T.L., Hendy, G.N. \& PAPapoulos, S.E. (1979) Measure ment of 1,25-Dihydroxycholecalciferol in man by radio-imm noassay. Clinical Endocrinology, 11, 225.

Cushard, Jr W.G., Simon, A.B., Canterbury, J.M. \& Reiss, (1972) Parathyroid function in sarcoidosis. New England Jogrnăl of Medicine, 286, 395.

DeLuCA, H.F. \& SCHNoEs, H.K. (1976) Metabolism and mech nism of action of vitamin D. Annual Review of Biochemistris 45 631

DENT, C.E. \& WATSON, L. (1966) Hyperparathyroidism ar sarcoidosis. British Medical Journal, 1, 646.

Papapoulos, S.E., Clemens, T.L., Fraher, L.J., Lewin, I. SANDLER, L.M. \& O'RIORDAN, J.L.H. (1979) 1,25-dihydroxycholecalciferol in the pathogenesis of the hypercalcaemia of sarcoid sis. Lancet, i, 627.

Robinson, R.G., KeRwin, D.M. \& Tsou, E. (1980) Parathyro adenoma with coexistent sarcoid granulomas. Archives of Internäl Medicine, 140, 1547.

TAYLOR, R.L., LYNCH, Jr H.J. \& WYSOR, Jr W.G. (1963) Seasona influence of sunlight on the hypercalcaemia of sarcoidosisi American Journal of Medicine, 34, 221.

WALTON, R.J. \& BIJVOET, O.L.M. (1975) Nomogram for derivati of renal threshold phosphate concentration. Lancet, ii, 309.

WinNaCKer, J.L., BeCKeR, K.L., Friedlander, M., Higgins, G.Д. Jr \& MOORE, C.F. (1969) Sarcoidosis and hyperparathyroidis. American Journal of Medicine, 46, 305.

ZerWeKh, J.E., PAK, C.C., KaPlan, R.A., MCGuire, J.L., Uß̊. ChURCh, K., BReslau, N. \& Johnson, R. (1980) Pathogenic ro\& of 1,25-dihydroxyvitamin $\mathrm{D}$ in sarcoidosis and absorptive hypes calcaemia: different response to prednisone therapy. Journal of Endocrinology and Metabolism, 51, 381.

(Accepted 29 December 1982) 